\title{
SELECTED DIPTERA FAMILIES CAUGHT WITH BEER TRAPS IN THE REPUBLIC OF MORDOVIA (RUSSIA)
}

\author{
Libor Dvořák1,**, Kateřina Dvořáková ${ }^{1}$, Jozef Oboňa², Alexander B. Ruchin ${ }^{3}$ \\ ${ }^{1}$ Tři Sekery, Czech Republic \\ ${ }^{2}$ Prešov University, Slovakia \\ ${ }^{3}$ Joint Directorate of the Mordovia State Nature Reserve and National Park «Smolny», Russia \\ *e-mail: lib.dvorak@seznam.cz
}

Received: 08.06.2020. Revised: 07.09.2020. Accepted: 08.09.2020.

\begin{abstract}
We have studied the fauna of several Diptera families caught with beer traps. In this paper, 36 species from 12 Diptera families are reported: four species of Anisopodidae, one species of Bibionidae, one species of Clusiidae, two species of Dryomyzidae, 11 species of Lauxaniidae, five species of Limoniidae, one species of Megamerinidae, three species of Pallopteridae, one species of Piophilidae, one species of Platystomatidae, four species of Sciomyzidae, and two species of Ulidiidae. From these species, three are new for Russia (Calliopum splendidum, Homoneura biumbrata, Sapromyza schnabli, all Lauxaniidae), two new for European Russia (Sylvicola fuscatoides (Anisopodidae), Myennis sibirica (Ulidiidae)). For the Republic of Mordovia and the Mordovia State Nature Reserve, the families Anisopodidae, Clusiidae, Megamerinidae, Pallopteridae, Piophilidae, Platystomatidae, Ulidiidae, and all Lauxaniidae species published in this list are recorded for the first time. Two species from the family Limoniidae (Achyrolimonia neonebulosa and Discobola parvispinula) and three species from the family Sciomyzidae (Euthycera chaerophylli, Tetanocera ferruginea and T. freyi) are recorded for the first time for the territory of the Mordovia State Nature Reserve. Beer traps can be recommended as one of the successful methods for future surveys of Diptera in the area of interest.
\end{abstract}

Key words: Anisopodidae, bait traps, Bibionidae, biodiversity, Clusiidae, Dryomyzidae, faunistic survey, Limoniidae, Mordovia State Nature Reserve, new records

\section{Introduction}

The order Diptera is among the most diverse insect orders. Its biological diversity contains at least 150000 species (Courtney et al., 2009), but annually new taxa are being described (e.g., Nourti et al., 2019). Diptera have successfully colonised all continents, including Antarctica, and virtually all habitats except the open sea and inland glaciers. However, the ranges of many species are being studied continuously. Information about the distribution of species and families extends every year (Chursina \& Ruchin, 2018a,b; Martín-Park et al., 2018; Astakhov et al., 2019; Gladun, 2019; Pilipenko et al., 2020; Mutin, 2020; Vikhrev et al., 2020). Diptera larvae of different families are found in various terrestrial and aquatic habitats, and can inhabit the tissues of plants and animals; many of them are saproxylic (Martín-Vega \& Baz, 2013; Grichanov \& Khruleva, 2018; Krivosheina \& Krivosheina, 2019).

Due to the considerable diversity of Diptera, there are also many ways to study them. Various devices and traps are used to study Diptera (Matthews \& Matthews, 1970; Disney et al., 1982; Baz et al., 2007; Castro et al., 2011; Cavallari et al., 2014). Catching Diptera using the fermental traps was thoroughly reported by Dvořáková (2008), Dvořák (2014) and Dvořák et al. (2017). Fermental traps with baits from a mixture of beer, sugar, honey, and jam have shown their effectiveness in detecting many Coleoptera (MacRae \& Rice, 2007; Guarnieri, 2009; Wong \& Hanks, 2016; Egorov \& Ivanov, 2018), Lepidoptera (El-Sayed et al., 2005; Uehara-Prado \& Freitas, 2009; Jakubíková \& Kadlec, 2015), Hymenoptera (Dvořák, 2007; Demichelis et al., 2014; Manko et al., 2019; Sorvari, 2019), and Neuroptera (Duelli et al., 2006; Makarkin \& Ruchin, 2019).

The Diptera fauna of the Republic of Mordovia is insufficiently known. Plavilshchikov (1964) summarised the knowledge of insects including Diptera from the territory of the Mordovia State National Reserve, and Feoktistov (2011) published new records for the Republic of Mordovia. Recently, the results of systematic studies of some Diptera families were published, including Bombyliidae (Chursina \& Ruchin, 2018a), Syrphidae (Chursina \& Ruchin, 2018b), Asilidae (Astakhov et al., 2019), Limoniidae, Pediciidae, and Tipulidae (Pilipenko et al., 2020). The purpose of the current study was to analyse the fauna of selected Diptera groups caught using beer traps. 


\section{Material and Methods \\ Study area}

The Republic of Mordovia is located in the centre of the East European Plain between 53.633$55.183^{\circ} \mathrm{N}$ and $42.183-46.750^{\circ} \mathrm{E}$ in the southwest part of the River Volga basin in the interfluve of the River Moksha and the River Sura. The study area is represented by forest and forest-steppe zones of Central Russia. Eastern Mordovia is located in the northwest periphery of the Volga Upland, while Western Mordovia in the Oka-Don Lowland. The landscape variability affects the diversity of habitats. Broad-leaved forests are located in the central and eastern part of the region, growing mainly in the floodplains of large rivers. In some parts of the region, broad-leaved forests of a secondary origin occur. Such forests have appeared on the former sites of old-growth deciduous forests that were cut down. In the northwest part of the Republic of Mordovia, large forests of old-growth coniferous and mixed forests are common. In the western part of the region, there is a large area of mixed and coniferous forests. The east and southeast of the area is predominated by a forest-steppe landscape (Ruchin \& Egorov, 2017, 2018; Khapugin \& Ruchin, 2019).

\section{Methods}

The study was carried out during the whole season of 2019. Each trap was a five-liter plastic container with a window cut out on one side, at a distance of $10 \mathrm{~cm}$ from the bottom. With the help of a load, a rope with a tied trap was thrown on a tree branch at a height of $1.5-10 \mathrm{~m}$ from the ground surface. In each case, fermenting beer was used as bait, with an addition of honey, jam, or sugar. The description of traps and their application methods are given in Ruchin et al. (2020a).

All the material was collected by the fourth author who selected Diptera from all samples (Appendix). Then the first author sorted the material into several families for the purpose of identification by particular authors. The list of families identified by individual authors is as follows: The first author identified Anisopodidae (Söli \& Rindal, 2014), Bibionidae (Krivosheina, 1989), Clusiidae (Shtakeberg, 1989c), Megamerinidae (Shtakeberg, 1989a), Pallopteridae (Ozerov, 2009), Piophilidae (Shtakeberg, 1989b), and Platystomatidae (Hendel, 1913; Hennig, 1945; Rikhter, 1989), the second author Dryomyzidae (Ozerov, 1987), Lauxaniidae (Shatalkin, 2000), and Sciomyzidae (Rozkošný, 1987), and the third author Limoniidae (Oosterbroek, 2020). The species of Ulidiidae were identified by V. Korneyev (National
Academy of Sciences of Ukraine, Kiev) from the photos taken by L. Dvořák. We use the abbreviation RU-RUC for Central European Russia according to the Fauna Europaea portal (https://fauna-eu.org). In the section Results, the taxa are listed alphabetically after family names (i.e. not systematically).

Abbreviations and symbols used in the Material paragraph for every species: MSNR - Mordovia State Nature Reserve, $\hat{O}-$ male, $ᄋ$ - female, $\mathrm{L}-$ low, H - high, T - Tilia cordata Mill., B - Betula pendula Roth, A - Alnus glutinosa (L.) Gaertn., Q - Quercus robur L., P - Pinus sylvestris L.).

\section{Results}

During the survey, the material from 67 traps was studied. Altogether 1062 specimens belonging to 36 species of 12 Diptera families were identified (see below, the sub-section Faunistics).

\section{Faunistics}

Family Anisopodidae

Sylvicola cinctus (Fabricius, 1787)

Material. Makarovka: 1 § , 6 우. Saransk: 1 ․ MSNR 5: $1 \hat{\jmath}, 1$ ․ . MSNR 24: $1 \hat{\jmath}$. MSNR 28: 2 웅. MSNR 30: 2 우오. MSNR 31:1 9 . MSNR 32: 1 수 1

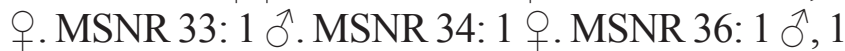

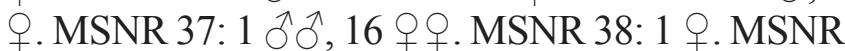

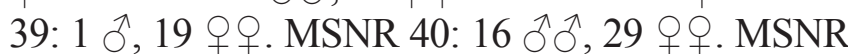
41, QL: 1 ‥ MSNR 41, AL: 2 ㅇ‥ MSNR 42, AH: 1 ㅇ. MSNR 42, QL: 2 오오. MSNR 43: 4 $\partial^{\lambda}, 3$ 오오. MSNR 45: 1 ㅇ․ MSNR 47: 4 우우. MSNR 50: 3 웅․ MSNR 51:2 우오. MSNR 52: 11 우오.

Comments. This is a common species with a large European distribution (Dvořák et al., 2019).

Sylvicola fuscatoides (Michelsen, 1999)

Material. Makarovka: 1 ㅇ. Saransk: 1 Oे. MSNR 1:3 웅. MSNR 2: 1 ․ MSNR 3:1 $0^{\lambda}, 2$ 우우. MSNR

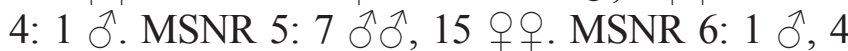
우. ․ MSNR 7: 1 ㅇ. MSNR 10: 11 웅. MSNR 11: 1 ․ MSNR 12: 1 ㅇ. MSNR 13: 1 \% , 3 우. MSNR 14: 6 오오. MSNR 16: 1 ㅇ. MSNR 17: 1 ㅇ. MSNR 18: 2 웅‥ MSNR 19: 3 우우. MSNR 20: 1 해, 6 우우. MSNR 21: 3 우․ MSNR 22: 1 $\hat{\jmath}, 1$ ․ MSNR 24: $1 \hat{\jmath}, 4$ 웅. MSNR 25: 2 $\hat{\jmath} \hat{\jmath}, 1$ ㅇ․ MSNR 26: 1 ㅇ. MSNR 27: $3{ }^{\lambda} \partial^{\lambda}, 3$ 웅. MSNR 29: 1 ․ MSNR 30:

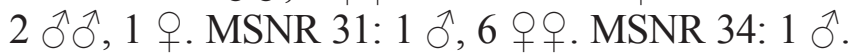
MSNR 35: 2 웅. MSNR 36: 1 ㅇ. MSNR 37: 1 ๙, 1 ․ MSNR 38: 1 ․ MSNR 40: 9 오. MSNR 41, PL: 6 우오. MSNR 41, PH: 2 웅․ MSNR 41, AL: 1 ㅇ. MSNR 42, TL: 1 ․ MSNR 45: 1 ․ MSNR 47: 1 के, 1 ․ MSNR 49: 1 $\hat{\delta}, 3$ 웅. MSNR 50: 1 $\delta$. MSNR 51: $3 \hat{\jmath} \widehat{\jmath}, 6$ 우우. MSNR 52: $2 \hat{\jmath} \widehat{0}, 7$ 우우. 
Comments. The occurrence of this species was published by Andersson (1967) and Krivosheina \& Menzel (1998) under the name S. fuscatus (Fabricius, 1775) on the basis of the material from Sweden and Asian Russia (Ussuri region). Michelsen (1999) stated that this name belongs to another species and described $S$. fuscatoides based on the diagnostic figures by Andersson (1967) and Krivosheina \& Menzel (1998). After that, several records were published from Poland (Haenni, 2006), Estonia (Kurina, 2006), Finland (Haarto, 2011), and Norway (Söli \& Rindal, 2014). The species seems to be a typical eastern boreal species, confined to coniferous forests (Söli \& Rindal, 2014). These are the first records from European Russia and the second record outside the boreal zone. The occurrence in the Republic of Mordovia is the southernmost record of this species (Fig. A,B,C). Hitherto, 67 specimens of $S$. fuscatoides were published from six regions worldwide. However, in this paper, in total 158 specimens are presented from the Republic of Mordovia (Table 1).
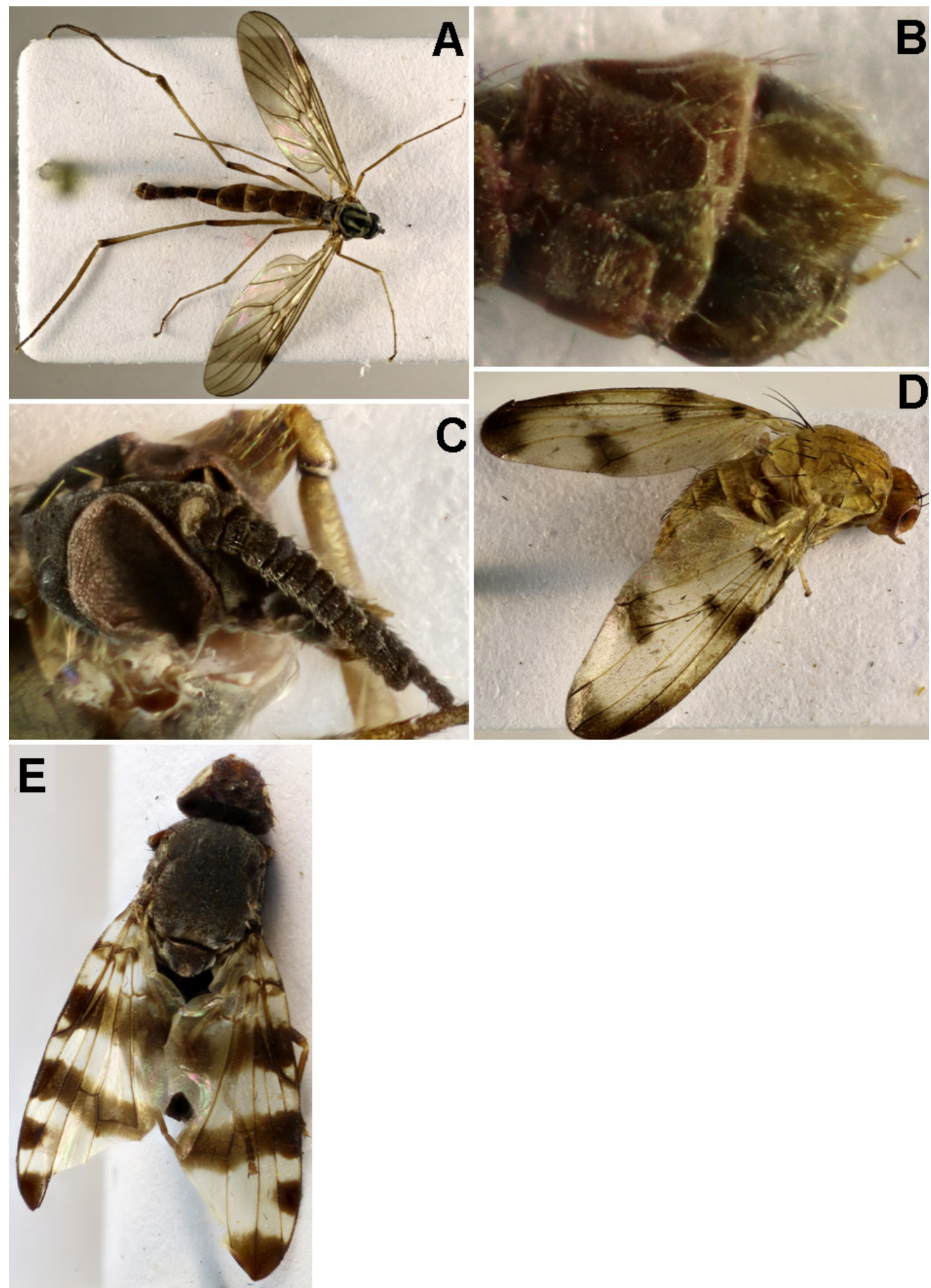

Fig. Diptera specimens caught in the Republic of Mordovia (Russia). Designations: A - Sylvicola fuscatoides male; B - Sylvicola fuscatoides male genitalia with one pointed lobe on hypoproct; $\mathrm{C}$ - Sylvicola fuscatoides female antenna with strongly widened basal flagellomeres; D - Toxoneura basimaculata male; E - Pseudotephritis millepunctata male (Photos: Ondřej Kouklík). 
Table 1. Number of specimens of Sylvicola fuscatoides published from various regions worldwide, compared to the Republic of Mordovia

\begin{tabular}{|l|c|l|}
\hline \multicolumn{1}{|c|}{ Region } & Number of specimens & \multicolumn{1}{|c|}{ Source } \\
\hline Estonia & 1 & Kurina (2006) \\
\hline Poland & 2 & Haenni (2006) \\
\hline Finland & 14 & Haarto (2011) \\
\hline Norway & 34 & Söli \& Rindal (2014) \\
\hline Sweden & 2 & Andersson (1967), Michelsen (1999) \\
\hline Asian Russia & 14 & Krivosheina \& Menzel (1998) \\
\hline In total: & 67 & \\
\hline Republic of Mordovia & 158 & This study \\
\hline
\end{tabular}

Sylvicola punctatus (Fabricius, 1787)

Material. Svinosovkhoz: 4 우. Makarovka: 7

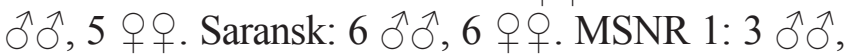
1 ‥ MSNR 2: 3 우. MSNR 3: 1 ․ MSNR 4: 2

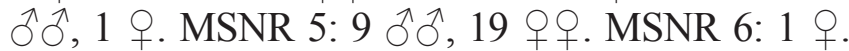
MSNR 12: 1 ․ MSNR 14: 1 ․ MSNR 21: 2 우. MSNR 22: 1 ․ MSNR 24: 2 우. MSNR 25: $2 \hat{\jmath} \hat{\jmath}$,

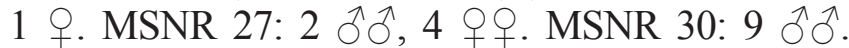
MSNR 31: 1 ․ MSNR 33: 2 ㅇ․ MSNR 34: 2 $\widehat{\jmath}$, 2 오. MSNR 35: 2 취, 17 웅. MSNR 36: 1 ㅊ, 1 ‥ MSNR 37: 1 ○े, 2 우. MSNR 38: 1 ․ MSNR 39: 1 ․ MSNR 40: 2 ㅇ․ MSNR 41, PL: 1 ․ MSNR 41, PH: 1 ${ }^{\lambda}, 1$ 1 . MSNR 41, QL: 1 ․ MSNR 41, QH: 1 q. MSNR 41, AH: 1 . . MSNR 41, AL: 4 q 9.

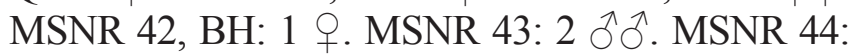

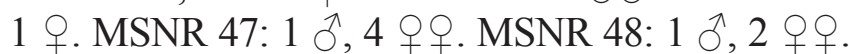
MSNR 49: 2 우. MSNR 50: 1 ${ }^{\lambda}, 2$ 우. MSNR 51:

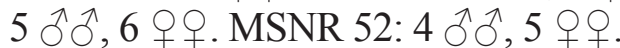

Comments. This is a common species, widely distributed across Europe (Dvořák et al., 2019).

Sylvicola stackelbergi Krivosheina \& Menzel, 1998 Material. MSNR 4: $1 \hat{\jmath}, 1$ ․ MSNR 5: $1 \hat{\jmath}$. MSNR 31: 1 $\widehat{\jmath}$. MSNR 35: 1 ㅇ.

Comments. The main part of the species range is restricted to Northern and North-East Europe. Isolated records are known from the Netherlands (Beuk, 2002), Slovakia (Ševčík, 2011), Austria (Dvořák, 2014), Armenia (Oboňa et al., 2017), and Romania (Dvořák et al., 2019). In Russia, the species is known from St. Petersburg, Vudyavr (Khibin Mts., Murmansk), Solovetsky Island, Yascera (near Luga, Leningrad region), and Nakhabino (Moscow region) (Krivosheina \& Menzel, 1998). Except the high number of $S$. fucatoides specimens caught during the present study, it is also interesting to compare the number of this species with other species of the genus Sylvicola, as shown in Table 2.

Family Bibionidae Bibio clavipes Meigen, 1818

Material. MSNR 30: 1 ก. MSNR 31: 1 ․

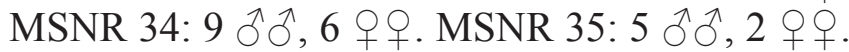

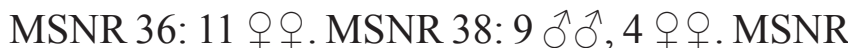

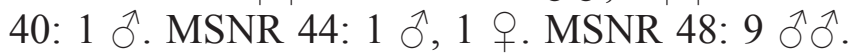
MSNR 49: 48 $\widehat{\jmath}, 9$ 우. MSNR 50: 2 $\widehat{\jmath}, 21$ 우. MSNR 51: 1 ㅇ. MSNR 52: 1 ${ }^{\lambda}$.

Comments. This is a species with a wide European distribution. It has been already known from the Republic of Mordovia (Feoktistov, 2011).

Family Clusiidae

Clusia tigrina (Fallén, 1820)

Material. MSNR 29: 1 ○.

Comments. This is a species with a wide European distribution, except for the southernmost and easternmost parts. It is also known from RU-RUC (Roháček \& Merz, 2013).

\section{Family Dryomyzidae}

Dryomyza anilis Fallén, 1820

Material. Saransk: 2 우. MSNR 1: 8 ふぇ, 11

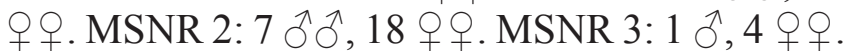

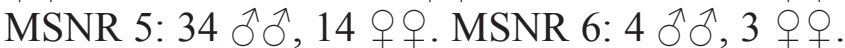
MSNR 13: 1 $\hat{\jmath}, 2$ 우. MSNR 14: 1 ․ MSNR 15: 1 ․ MSNR 16: 1 ${ }^{\lambda}$. MSNR 17: 1 ․ MSNR 19: $1 \hat{\jmath}$. MSNR 20: $1 \hat{\jmath}$. MSNR 22: 1 $\hat{\sigma}, 1$ q. MSNR 26: 1 $\hat{\jmath}$. MSNR 31: $1 \hat{\jmath}, 5$ ㅇ‥ MSNR 33: $1 \hat{\jmath}, 1$ ๆ. MSNR 34: 1 q. MSNR 37: 2 $\hat{\jmath}$. MSNR 39: 1

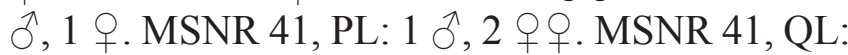

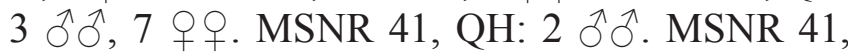
AH: 1 $\hat{\jmath}$. MSNR 41, AL: 18 $\hat{\jmath}, 1$ ‥ MSNR 42, TL: 1 ๙ิ. MSNR 42, AL: 6 $\widehat{\jmath}, 2$ 우․ MSNR 42,

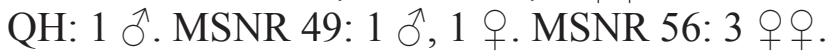

Comments. This is a common and widely distributed species, known from Canada, USA, Europe, Korea, Japan, Russian Far East (Mathis \& Sueyoshi, 2011), RU-RUC (Soós, 1984b).

Table 2. Number of caught specimens for selected Sylvicola species and their proportional representation

\begin{tabular}{|l|c|c|}
\hline \multicolumn{1}{|c|}{ Species } & Specimens & Percentage, $\%$ \\
\hline Sylvicola cinctus & 139 & 29.1 \\
\hline Sylvicola fuscatoides & 158 & 33.1 \\
\hline Sylvicola punctatus & 176 & 36.8 \\
\hline Sylvicola stackelbergi & 5 & 1.0 \\
\hline All species together & 478 & 100.0 \\
\hline
\end{tabular}


Dryope decrepita (Zetterstedt, 1838)

Material. MSNR 43: 1 ऽ.

Comments. This is a species known from several regions in Canada, USA, Asian Russia, and Europe, except for the southern parts. It is known also from European Russia (Mathis \& Sueyoshi, 2011). In the Republic of Mordovia, it has been reported already by Plavilshchikov (1964).

Family Lauxaniidae

Aulogastromyia anisodactyla (Loew, 1845)

Material. MSNR 52: 1 ․

Comments. This species is known from most of Europe, and also from RU-RUC (Merz, 2013).

Calliopum simillimum (Collin, 1933)

Material. MSNR 42, AL: 3 $ぇ$.

Comments. This species is known from most of Europe, also from RU-RUC (Merz, 2013).

\section{Calliopum splendidum Papp, 1978}

Material. MSNR 43: 1 ․

Comments. This species is known from Western, Southern, and Central Europe and also from the Near East (Merz, 2013). The present record in the Republic of Mordovia is the first for Russia.

Homoneura biumbrata (Loew, 1847)

Material. MSNR 42, AL: $1 \hat{\jmath}$.

Comments. This is a rare species known from western and middle parts of Europe (Merz, 2013). The present record in the Republic of Mordovia is the first for Russia.

Meiosimyza decempunctata (Fallén, 1820)

Material. Svinosovkhoz: 1 ․ Kalinovka: 1 $\delta$. Makarovka: 1 q. Saransk: 1 ${ }^{\lambda}$. MSNR 34: 1 q. MSNR 42, BH: 1 q.

Comments. This species is known from most of Europe, and also from RU-RUC (Merz, 2013).

Meiosimyza rorida (Fallén, 1820)

Material. MSNR 2: 1 o. MSNR 29: 1 ․ MSNR 33: 1 ㅅ, 14 우. MSNR 37: 11 우. MSNR 38: 1 ․ MSNR 39: 4 우. MSNR 41, QL: 1 ․ MSNR 41, AH: 1 q. MSNR 41, AL: 1 ${ }^{\top}$. MSNR 42, AL: 3 우. MSNR 48: 1 ․ MSNR 49: 4 우. MSNR 52: 1 ō, 8 우오.

Comments. This species is known from most of Europe, the Near East, and North America, and also from RU-RUC (Merz, 2013).
Meiosimyza subfasciata (Zetterstedt, 1838)

Material. MSNR 26: 1 q. MSNR 39: 1 ก.

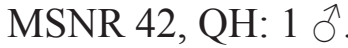

Comments. This species is known from $\mathrm{Eu}-$ rope, except for the Iberian Peninsula, most of the Balkans, Eastern Europe, and also from the Near East. It is the first records for RU-RUC.

Minettia lupulina (Fabricius, 1787)

Material. MSNR 26: 2 우.

Comments. This species is known from most of Europe. It is the first record from RU-RUC.

Minettia plumicornis (Fallén, 1820)

Material. Saransk: 1 $\delta$.

Comments. This species is known from most of Europe, and also from RU-RUC (Merz, 2013).

Pseudolyciella pallidiventris (Fallén, 1820)

Material. Makarovka: 1 ․ Saransk: 1 गे, 2 우. MSNR 1: 1 ○. MSNR 26: 1 ․.

Comments. This species is known from most of Europe, and also from RU-RUC (Merz, 2013).

Sapromyza schnabli Papp, 1987

Material. MSNR 37: 1 \%.

Comments. This is a poorly known European species, recorded only from some countries: Austria, Belarus, the Czech Republic, France, Hungary, Poland, Romania, Slovakia, and Switzerland. It is the first record for Russia.

Family Limoniidae

Achyrolimonia neonebulosa (Alexander, 1924)

Material. MSNR 15: 1 o.

Comments. This is a common Holarctic species with a large distribution area (Asia, Europe, USA, Russia including RU-RUC (Tver region), North Caucasus, West Siberia (Altay), Russian Far East (Primorsky Krai, Sakhalin region) (Pilipenko et al., 2019; Oosterbroek, 2020).

Discobola parvispinula (Alexander, 1947)

Material. MSNR 33: 1 กิ, 1 ค. MSNR 41, QL: 1 o. MSNR 41, AH: 1 ex.

Comments. This is a Palaearctic species know from Europe, Japan, and Russia including RU-RUC, West Siberia (Altay), East Siberia (Krasnoyarsky Krai), and the Russian Far East (Amur region, Primorsky Krai, Sakhalin region, Kuril Islands) (Pilipenko et al., 2019; Oosterbroek, 2020). 
Limonia macrostigma (Schummel, 1829)

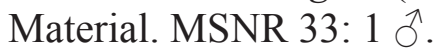

Comments. This is a Palaearctic and Oriental species, common in Europe and Asia. In Russia, it is known from almost all parts including the Republic of Mordovia, West Siberia (Altay), Russian Far East (Primorsky Krai) (Pilipenko et al., 2019; Oosterbroek, 2020).

Metalimnobia bifasciata (Schrank, 1781)

Material. MSNR 7: 1 . MSNR 9: $1 \hat{\jmath}$. MSNR 13: 1 ․ . MSNR 22: 2 $\jmath^{\jmath}$. MSNR 31: 1 O. MSNR

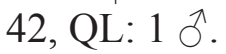

Comments. This is Palaearctic and Oriental species, common in Europe and Asia. In Russia, it is known from almost all parts including the Republic of Mordovia, Siberia, Russian Far East (Kamchatka, Amur region, Primorsky Krai, Sakhalin region, Kuril Islands) (Pilipenko et al., 2019; Oosterbroek, 2020).

Metalimnobia quadrimaculata (Linnaeus, 1760)

Material. MSNR 3: 1 ㅇ. MSNR 4: 2 우.

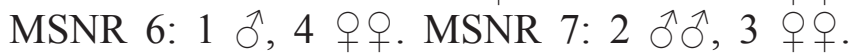

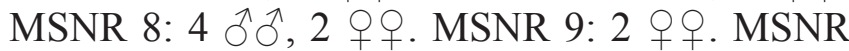

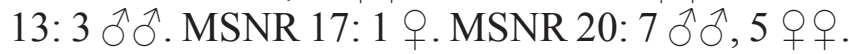
MSNR 22: $1 \hat{\jmath}$. MSNR 23: $2 \hat{\jmath}$. MSNR 33: 1 q.

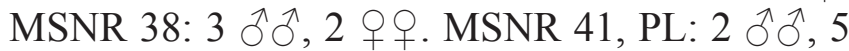
우. MSNR 41, PH: 1 ‥ MSNR 41, QL: 5 ふ઼ 오. MSNR 41, QH: 1 ô, 1 ․ . MSNR 41, AH: 2

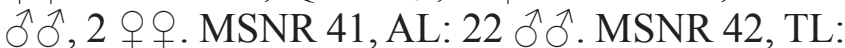

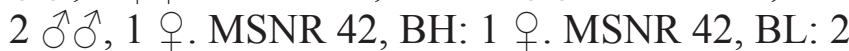

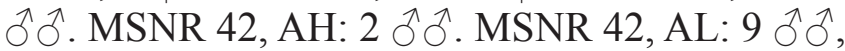

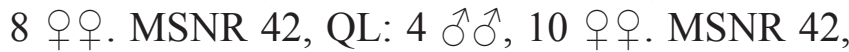
QH: $1 \hat{\jmath}, 1$ ․ MSNR 52: 1

Comments. This is a Holarctic species, common in Europe, Asia and the USA. In Russia, it is known from almost all parts including the Republic of Mordovia, Siberia, the Russian Far East (Kamchatka, Amur region, Primorsky Krai, Sakhalin region, Kuril Islands) (Pilipenko et al., 2019; Oosterbroek, 2020).

Family Megamerinidae

Megamerina dolium (Fabricius, 1805)

Material. MSNR 4: 1 q.

Comments. This is a widely distributed European species, known also from RU-RUC (Nartshuk, 1984).

Family Pallopteridae

Palloptera ustulata Fallén, 1820

Material. MSNR 52: 1 ㅇ.

Comments. This species is known from Europe, Primorsky Krai, and Kazakhstan, and also from RU-RUC (Ozerov, 2009). Recently, it was newly reported from Turkey (Yaran, 2019).

Toxoneura basimaculata (Czerny, 1934)

Material. MSNR 5: 1 . MSNR 50: 1 q.

Comments. So far this rarely collected species was known from Austria, Croatia, the Czech Republic, Germany, Hungary, Italy, Kazakhstan, Poland, and Russia (Yaroslavl region, Samara region, Republic of Dagestan) (Ozerov, 2009; Merz, 2013). The newest records were published from Slovakia (Dvořák, 2012) and Turkey (Yaran, 2019). Only its record in the Samarskaya Luka National Park (Rosenberg, 2007) is relatively close to the Republic of Mordovia. It is the first records from RU-RUC (Fig. D).

Toxoneura usta (Meigen, 1830)

Material. MSNR 41, PL: 1 +. MSNR 41, PH: 1 ․ MSNR 50: 1 ․

Comments. This species is known from $\mathrm{Eu}-$ rope including European Russia, and also from the Republic of Altai and Primorsky Krai (Ozerov, 2009). The records in the Republic of Mordovia are the first for RU-RUC.

Family Piophilidae

Mycetaulus bipunctatus (Fallén, 1823)

Material. MSNR 25: 5 $ぇ, 1$ ․ MSNR 26: 1 ․

Comments. This species has a wide distribution, including Europe (the Czech Republic, Great Britain, France (mainland), Finland, Germany, the Netherlands, Poland, Slovakia, Sweden, Switzerland (Ozerov, 2013)), Russia (European Russia; Caucasus; Russian Far East) (Ozerov, 1999)), Crimea (mainland) (Bukowski, 1940; Misiachna \& Korneyev, 2015), Asia (Kyrgyzstan (Ozerov, 1999)).

Family Platystomatidae

Platystoma lugubre (Robineau-Desvoidy, 1830)

Material. MSNR 4: 4 우. MSNR 5: 2 우. MSNR 7: 1 ․ MSNR 42, BL: 2 $\widehat{\jmath}$. MSNR 42, QL: 1 \%.

Comments. This species is known from the temperate and southern parts of Europe, Caucasus, and Turkey (Soós, 1984a), and also from RU-RUC (Lyubvina, 2016).

\section{Family Sciomyzidae}

Euthycera chaerophylli (Fabricius, 1798)

Material. MSNR 21: 1 q. MSNR 22: 1 q.

Comments. This is a common species, known from almost the whole of Europe, Turkey, and also from RU-RUC (Rozkošný, 2013). 
Tetanocera elata (Fabricius, 1781)

Material. MSNR 5: 1 ㅇ.

Comments. This is a widely distributed Palaearctic species, known also from RU-RUC (Rozkošný, 2013).

Tetanocera ferruginea Fallén, 1820

Material. MSNR 1: 1 7 .

Comments. This is a widely distributed Holarctic species, known also from RU-RUC (Rozkošný, 2013).

Tetanocera freyi Stackelberg, 1963

Material. MSNR 2: 1 0 .

Comments. This is a species of Western and Northern Europe, known from France to North European Russia and also from North America (Rozkošný, 2013). It is the first record for RU-RUC.

Family Ulidiidae

\section{Myennis sibirica Portschinsky 1892}

Material. MSNR 2: 1 q. MSNR 4: 1 q.

Comments. This species is known from the southern part of the Russian Far East (Krivosheina \& Krivosheina, 1997; Kameneva \& Korneyev, 2006), Korea (Han, 2013), and from Ukraine (Kameneva et al., 2013). The records in the Republic of Mordovia are the first for European Russia.

\section{Pseudotephritis millepunctata (Hennig, 1939)}

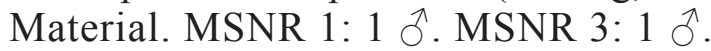

Comments. The presented records are reported also in Ruchin et al. (2020b). Our material covers in total ten localities of this species (35 specimens) in the Republic of Mordovia (Ruchin et al., 2020b) (Fig. E).

\section{Dominancy and frequency occurrence}

The most abundant species were Dryomyza anilis (181 specimens), Sylvicola punctatus (176 specimens), S. fuscatoides (158 specimens), Bibio clavipes (141 specimens), Sylvicola cinctus (139 specimens), and Metalimnobia quadrimaculata (136 specimens). Almost the same species were the most frequent in the traps: $S y l$ vicola fuscatoides (44 samples), S. punctatus (41 samples), Dryomyza anilis (30 samples), Metalimnobia quadrimaculata (27 samples), and Sylvicola cinctus (25 samples).

The traps with the highest numbers of captured Diptera specimens were MSNR 5 (105 specimens), MSNR 49 (69 specimens), MSNR
40 (57 specimens), MSNR 41, AL (49 specimens), and MSNR 52 (45 specimens). The highest species diversity was documented from the following traps: MSNR 52 (nine species), MSNR 5 (eight species), Saransk, MSNR 1, MSNR 4, MSNR 31, and MSNR 33 (each with seven species).

\section{Affinity to forest types}

For the comparison of the frequency occurrence of the caught species, all localities were divided into established in deciduous forest (22 localities), mixed forest (27 localities), and pine (Pinus sylvestris L.) forest (14 localities). Of 36 species identified during the survey, 27 species were trapped in deciduous forest, 24 species in mixed forest, and only 13 species in pine forest. Noteworthy, the species Dryope decrepita and Calliopum splendidum were trapped only in pine forest.

For a more precise evaluation of affinity to selected forest types, we suggest the following 13 most common (most frequently occurred) species: Sylvicola cinctus, S. fuscatoides, S. punctatus, S. stackelbergi, Bibio clavipes, Dryomyza anilis, Meiosimyza decempunctata, M. rorida, M. subfasciata, Pseudolyciella pallidiventris, Metalimnobia bifasciata, M. quadrimaculata, and Platystoma lugubre. The following three aspects were chosen for the comments.

- Percentage of localities in each forest type, where the species was found. Almost all species were found to be the rarest in the mixed forests. Three common Sylvicola species (S. cinctus, $S$. fuscatoides, S. punctatus) occupied considerably more localities in deciduous and pine forests than in mixed forests. Bibio clavipes was trapped noticeably most often in pine forest, while Dryomyza anilis and Metalimnobia quadrimaculata in deciduous forest. Interesting is the trapping of Meiosimyza subfasciata in mixed forest, while it was absent in both other forest types. Evaluating of all 13 species shows that nine of them have the highest average abundance in deciduous forests, two of them in pine forests, and two of them in mixed forests.

- In each forest type, the average abundance of species counted as the sum of specimens in the forest type divided by the number of localities in this forest type. Three common Sylvicola species ( $S$. cinctus, S. fuscatoides, S. puncta$t u s$ ) were more abundant in deciduous and pine forests compared to mixed forests. Bibio clavi- 
pes was most abundant in pine forests, while Dryomyza anilis in deciduous forests. Metalimnobia quadrimaculata was abundant in deciduous forests, less abundant in mixed forests, and non-abundant in pine forests. The evaluation of seven species (as the differences in the other six were minimal) shows that five of them have the highest average abundance in deciduous forests, two of them in pine forests, and none of them in mixed forests.

- Maximum abundance of specimens in one trap. The analysis shows almost the same results as in the previous paragraphs. Sylvicola spp. had the highest abundance values in deciduous and in pine forests, Bibio clavipes in pine forests, Dryomyza anilis in deciduous forests, and Metalimnobia quadrimaculata in deciduous forests and slightly lower in mixed forests. Meiosimyza rorida has a higher abundance in mixed forests and slightly lower abundance in deciduous forests compared to pine forests. The evaluation of 11 species (as the differences in the other two were minimal) shows that seven of them have the highest abundance in deciduous forests, two of them in pine forests, and two in mixed forests.

\section{Discussion}

Concurrently with advancing research in the fields of ecology and nature conservation, taxonomists have acquired a considerable amount of knowledge in species diversity. The availability of this scientific knowledge varies greatly over space, time, taxa, and type of information, creating gaps in biodiversity information (Amano et al., 2016). Particularly Diptera are often exemplary in this respect. The knowledge of the biodiversity is crucial from the conservation point of view. Collecting in the Republic of Mordovia was designed to reduce the gap in the knowledge of Diptera and other invertebrates. Very popular, efficient, cheap and simple passive methods of insect sampling are bait traps (e.g., Manko et al., 2019; Dvořák et al. 2019). Beer (with various additions and modifications) is very commonly used as bait, attracting especially Diptera, Mecoptera and other insect groups (e.g., Dvoŕák et al., 2017; Oboňa et al., 2017). This method is very attractive because it can be also used for monitoring of the occurrence and distribution of pests or parasites; furthermore it is able to capture rare and little-known species (e.g., like in the pres- ent study). A thorough knowledge of biodiversity is a suitable pillar for further special and applied research.

By analysing the results of dominancy, frequency, and affinity to forest types we can assume that Sylvicola fuscatoides, S. punctatus, and $S$. stackelbergi had the optimum in deciduous forests with the respect to all three above mentioned parameters, and Sylvicola cinctus in pine forests. All four Anisopodidae species had the lowest abundance in mixed forests. Bibio clavipes was the most frequent and abundant in pine forests, less abundant in mixed forests, and least abundant in deciduous forests. Completely other abundance values were found for Dryomyza anilis, which was abundant in deciduous forests, and less abundant in mixed and pine forests. No considerable differences were found for Lauxaniidae species, but members of this family occurred less frequently in pine forests. Data for Metalimnobia bifasciata did not show any remarkable results, while Metalimnobia quadrimaculata had preferences similar to those for Dryomyza anilis, being abundant in deciduous forests and less abundant in mixed and pine forests. Platystoma lugubre occurred almost evenly everywhere. But it seems that it slightly prefers deciduous forests. No species of the families Pallopteridae and Sciomyzidae were found in pine forests. All Ulidiidae species were found only in deciduous forests.

The obtained results show that the deciduous forests are the most diverse in terms of Diptera species. The results obtained in mixed forests were similar to deciduous forest. But this forest type is not so diverse in terms of species. In the pine forests, the species composition was the least diverse, some species are missing or less abundant compared to deciduous and mixed forests.

\section{Acknowledgements}

The authors thank Valery A. Korneyev (I.I. Schmalhausen Institute of Zoology National Academy of Sciences of Ukraine, Ukraine) for the identification of the specimens from the family Ulidiidae and two anonymous reviewers for their helpful notes. We wish to thank Ondřej Kouklík (Charles University, Czech Republic) for taking the photos of specimens.

\section{References}

Amano T., Lamming J.D.L., Sutherland W.J. 2016. Spatial Gaps in Global Biodiversity Information and the Role of Citizen Science. Bioscience 66(5): 393-400. DOI: 10.1093/biosci/biw022 
Andersson H. 1967. Notes on Swedish Diptera. Opuscula entomologica 32: 121-122.

Astakhov D.M., Ruchin A.B., Romadina O.D., Pristrem I.M. 2019. To robber flies fauna (Diptera: Asilidae) of Mordovia, Russia. Biodiversitas 20(4): 994-1005. DOI: 10.13057/biodiv/d200409

Baz A., Cifrián B., Díazäranda L.M., Martín-Vega D. 2007. The distribution of adult blow-flies (Diptera: Calliphoridae) along an altitudinal gradient in Central Spain. Annales de la Société Entomologique de France 43(3): 289-296. DOI: 10.1080/00379271.2007.10697524

Beuk P.L.T. 2002. Family Anisopodidae. In: P.L.T. Beuk (Ed.): Checklist of the Diptera of the Netherlands. Utrecht: KNNV Uitgeverij. P. 90.

Bukowski W. 1940. List of the dipteran insects collected in the Crimean Nature Reserve. Proceedings of the Crimean Nature Reserve 2: 189-216. [In Russian]

Castro C.P., Sousa J.P., Arnaldos M.I., Gaspar J., García M.D. 2011. Blowflies (Diptera: Calliphoridae) activity in sun exposed and shaded carrion in Portugal. Annales de la Société entomologique de France 47(1-2): 128-139. DOI: 10.1080/00379271.2011.10697704

Cavallari M.L., Baltazar F.N., Carvalho E.C., Muñoz D.R., Tolezano J.E. 2014. A Modified Shannon Trap for Use in Forensic Entomology. Advances in Entomology 2(2): 69-75. DOI: 10.4236/ae.2014.22012

Chursina M.A., Ruchin A.B. 2018a. A checklist of Bombyliidae (Diptera) from Mordovia, Russia and variation of wing shape in Bombylius species. Biodiversitas 19(6): 2147-2156. DOI: 10.13057/biodiv/d190622

Chursina M.A., Ruchin A.B. 2018b. A checklist of Syrphidae (Diptera) from Mordovia, Russia. Halteres 9: 57-73. DOI: 10.5281/zenodo.1255874

Courtney G.W., Pape T., Skevington J.H., Sinclair B.J. 2009. Biodiversity of Diptera. In: R.G. Foottit, P.H. Adler (Eds.): Insect Biodiversity: Science and Society. Blackwell Publishing Ltd. P. 185-222. DOI: 10.1002/9781444308211.ch9

Demichelis S., Manino A., Minuto G., Mariotti M., Porporato M. 2014. Social wasp trapping in North West Italy: comparison of different bait-traps and first detection of Vespa velutina. Bulletin of Insectology 67(2): 307-317.

Disney R.H.L., Erzinclioglu Y.Z., Henshaw D.J., Howse D., Unwin D.M., Withers P., Woods A. 1982. Collecting methods and the adequacy of attempted fauna surveys with reference to the Diptera. Field Studies 5: 607-621.

Duelli P., Moretti M., Tonolla D., Barbalat S. 2006. Scented traps yield two large lacewing species (Neuroptera, Chrysopidae) new to Switzerland. Bulletin de la Société Entomologique Suisse 79: 25-28. DOI: $10.5169 /$ seals-402909

Dvořák L. 2007. Social wasps (Hymenoptera: Vespidae) trapped with beer in European forest ecosystems. Acta Musei Moraviae, Scientiae Biologicae 98: 181-204.
Dvořák L. 2012. The first record of Toxoneura basimaculata (Diptera: Pallopteridae) from Slovakia. Klapalekiana 48: 224

Dvořák L. 2014. Window gnats (Diptera: Anisopodidae) from beer traps in various countries across Europe. Mitteilungen der Schweizerischen Entomologischen Gesellschaft 87: 247-254.

Dvořák L., Haenni J.P., Máca J., Mariychuk R., Oboňa J. 2017. Some insects (Dermaptera, Diptera, Mecoptera) from beer traps in Uzhhorod City (Ukraine). Folia Oecologica 9(2): 11-17.

Dvořák L., Kolcsár L.P., Georgiev D., Mariychuk R. 2019. New and interesting records of window-gnats (Anisopodidae: Diptera) from Europe. Klapalekiana 55(3-4): 187-192.

Dvořáková K. 2008. Heleomyzidae and Lauxaniidae (Diptera, Brachycera, Acalyptrata) trapped in the Czech Republic with syrup and fermented fruit. Linzer Biologische Beiträge 40(1): 507-515.

Egorov L.V., Ivanov A.V. 2018. Beetles (Insecta, Coleoptera), collected by fermenting bait crown traps in Chuvashia. Proceedings of the Mordovia State Nature Reserve 21: 191-204. [In Russian]

El-Sayed A.M., Heppelthwaite V.J., Manning L.M., Gibb A.R., Suckling D.M. 2005. Volatile constituents of fermented sugar baits and their attraction to lepidopteran species. Journal of Agricultural and Food Chemistry 53(4): 953-958. DOI: 10.1021/jf048521j

Feoktistov V.F. 2011. List of insect groups, for the first time recorded in the Mordovia State Nature Reserve and its neighbouring areas. Mordovia University Bulletin 4: 83-89. [In Russian]

Gladun V.V. 2019. The first record of Hermetia illucens (Diptera, Stratiomyidae) from Russia. Nature Conservation Research 4(4): 111-113. DOI: 10.24189/ncr.2019.063

Grichanov I.Ya., Khruleva O.A. 2018. Fauna and ecology of Dolichopodidae (Diptera) from Wrangel Island Nature Reserve (Chukotka, Russia). Nature Conservation Research 3(3): 37-45. DOI: 10.24189/ncr.2018.023

Guarnieri F.G. 2009. A survey of longhorned beetles (Coleoptera: Cerambycidae) from Paw Paw, Morgan County, West Virginia. Maryland Entomologist 5(1): 11-22.

Haarto A. 2011. Suomen ikkunasääsket - Finnish window gnats (Diptera, Anisopodidae). W-album 10: 3-13.

Haenni J.P. 2006. Faunistic and taxonomic notes on European Anisopodidae (Diptera). Studia Dipterologica 13(1): 27-28, 43-44.

Han H.Y. 2013. A checklist of the Families Lonchaeidae, Pallopteridae, Platystomatidae, and Ulidiidae (Insecta: Diptera: Tephritoidea) in Korea with notes on 12 species new to Korea. Animal Systematics, Evolution and Diversity 29(1): 56-69. DOI: 10.5635/ ASED.2013.29.1.56

Hendel F. 1913. Die Gattung Platystoma Meigen (Dipt.). Eine monographische Ubersicht uber die Arten. Zoolo- 
gische Jahrbucher. Abteilung fur Systematik, Ökologie und Geographie der Tiere 35(1): 55-126.

Hennig W. 1945. Platystomidae. In: E. Lidner (Ed.): Die Fliegen der palaearktischen Region. Vol. 5(1). Stuttgart: Schweizerbart. P. 1-56.

Jakubíková L., Kadlec T. 2015. Butterfly bait traps versus zigzag walks: What is the better way to monitor common and threatened butterflies in non-tropical regions? Journal of Insect Conservation 19(5): 911-919. DOI: 10.1007/s10841-015-9809-y

Kameneva E.P., Korneyev V.A. 2006. Myennidini, a new tribe of the subfamily Otitinae (Diptera: Ulidiidae), with discussion of the suprageneric classification of the family. Israel Journal of Entomology 3536(2005/6): 497-586.

Kameneva E.P., Korneyev V.A., Prokhorov A.V. 2013. The first record of Myennis sibirica Portschinsky (Diptera: Ulidiidae) from Europe. Ukrainska Entomofaunistyka 4(2): 20.

Khapugin A.A., Ruchin A.B. 2019. Red Data Book vascular plants in the Mordovia State Nature Reserve, a Protected Area in European Russia. Wulfenia 26: 53-71.

Krivosheina N.P. 1989. 31. Family Bibionidae. In: G.Y. BeiBienko, G.C. Steyskal (Eds.): Keys to the Insects of the European Part of the USSR. Vol. 5: Diptera and Siphonaptera, Part 1. Leiden: Brill. P. 667-680.

Krivosheina N.P., Krivosheina M.G. 1997. Revising palaearctic species of the genus Myennis (Diptera, Otitidae). Zoologicheskii Zhurnal 76(5): 628-632.

Krivosheina N.P., Krivosheina M.G. 2019. Saproxylic Diptera (Insecta) of the Lazovsky State Nature Reserve (Russia). Nature Conservation Research 4(3): 78-92. DOI: 10.24189/ncr.2019.052

Krivosheina N.P., Menzel F. 1998. The Palaearctic species of the genus Sylvicola Harris, 1776 (Diptera, Anisopodidae). Beiträge zur Entomologie 48: 201-217.

Kurina O. 2006. A review of Estonian wood gnats (Diptera: Anisopodidae). Sahlbergia 11: 18-22.

Lyubvina I.V. 2016. To the fauna of Diptera, Brachycera of the Penza region. In: N.A. Leonova (Ed.): Modern concepts of biosystem ecology of and their role in solving problems in nature conservation and management. Penza. P. 124-126. [In Russian]

Makarkin V.N., Ruchin A.B. 2019. New data on Neuroptera and Raphidioptera of Mordovia (Russia). Caucasian Entomological Bulletin 15(1): 147-157. DOI: 10.23885/181433262019151-147157 [In Russian]

Manko P., Demková L., Kohútová M., Oboňa J. 2019. Efficiency of traps in collecting selected Diptera families according to the used bait: comparison of baits and mixtures in a field experiment. European Journal of Ecology 4(2): 92-99. DOI: 10.2478/eje-2018-0016

Martín-Park A., Delfín-González H., Sosenski P., ReyesNovelo E., Meléndez-Ramírez V., Navarrete-Carballo J., Ibáñez-Bernal S., Dzul-Manzanilla F., González-Moreno A., Manrique-Saide P. 2018. Di- versity of Tabanidae, Asilidae and Syrphidae (Diptera) in natural protected areas of Yucatan, Mexico. Journal of Insect Conservation 22(1): 85-97. DOI: 10.1007/s10841-017-0040-x

Martín-Vega D., Baz A. 2013. Comparative larval morphology of the European bone-skippers, Thyreophora cynophila (Panzer, 1798) and Centrophlebomyia furcata (Fabricius, 1794) (Diptera: Piophilidae), with notes on their coexistence and natural history. Journal of Natural History 48(5-6): 285-299. DOI: 10.1080/00222933.2013.791938

Mathis W.N., Sueyoshi M. 2011. World Catalog and Conspectus on the Family Dryomyzidae (Diptera: Schizophora). MYIA 12: 207-233.

Matthews R.W., Matthews J.R. 1970. Malaise trap studies of flying insects in a New York mesic forest I. Ordinal composition and seasonal abundance. Journal of the New York Entomological Society 78(1): 52-59.

MacRae T.C., Rice M.E. 2007. Biological and Distributional Observations on North American Cerambycidae (Coleoptera). The Coleopterists Bulletin 61(2): 227-263. DOI: 10.1649/0010-065X(2007)61[227:B ADOON]2.0.CO;2

Merz B. 2013. Fauna Europaea: Pallopteridae. In: P. Beuk, T. Pape (Eds.): Fauna Europaea: Diptera Brachycera. Fauna Europaea version 2017.06. Available from https://fauna-eu.org/cdm_dataportal/taxon/1633da31609f-4e01-a2ca-87995b5f7b93

Michelsen V. 1999. Wood gnats of the genus Sylvicola (Diptera, Anisopodidae): taxonomic status, Family assignment, and review of nominal species described by J. C. Fabricius. Tijdschrift voor Entomologie 142: 69-75.

Misiachna A.V., Korneyev V.A. 2015. The first records of the skipper flies (Diptera, Piophilidae) from Ukraine. Vestnik Zoologii 49(2): 113-118. DOI: 10.1515/ vzoo-2015-0012

Mutin V.A. 2020. New data on hoverflies (Diptera: Syrphidae) from Russian Far East. Far Eastern Entomologist 403: 20-24. DOI: 10.25221/fee.403.3

Nartshuk E.P. 1984. Family Megamerinidae. In: A. Soos, L. Papp (Eds.): Catalogue of palaearctic Diptera. Vol. 9. Budapest: Akademia Kiado. P. 25-26.

Nourti M., Grichanov I.Ya., Kettani K. 2019. A new species of Teuchophorus (Dolichopodidae, Diptera) from Morocco. Nature Conservation Research 4(4): 106-110. DOI: $10.24189 /$ ncr.2019.064

Oboňa J., Dvořák L., Haenni J.P., Manko P., Hrivniak L., Papyan L. 2017. New records of Diptera families Anisopodidae, Bibionidae, Dixidae, Ptychopteridae and Scatopsidae from Armenia. Spixiana 40(1): 61-67.

Oosterbroek P. 2020. Catalogue of the Craneflies of the world (Diptera, Tipuloidea, Pediciidae, Limoniidae, Cylindrotomidae, Tipulidae). Available from www. ccw.naturalis.nl 
Ozerov A.L. 1987. Dipterans of the family Dryomyzidae in the fauna of the USSR. Bulletin of Moscow Society of Naturalists 92(4): 36-42. [In Russian]

Ozerov A.L. 1999. 75. Fam. Piophilidae. In: P.A. Lehr (Ed.): Keys to insects of Russian Far East. Vol. 6. Part 1: Diptera and Siphonaptera. Vladivostok: Dalnauka. P. 534-537.

Ozerov A.L. 2009. Review of the Family Pallopteridae (Diptera) of the Fauna of Russia. Russian Entomological Journal 18(2): 129-146. [In Russian]

Ozerov A.L. 2013. Fauna Europaea: Piophilidae. In: T. Pape, P. Beuk (Eds.): Fauna Europaea: Diptera: Brachycera. Fauna Europaea version 2017.06. Available from https://fauna-eu.org/cdm_dataportal/taxon/089fdc7e035d-424b-9c7f-855397fe0c56

Pilipenko V., Ruchin A.B., Semishin G.B. 2020. Cranefly fauna (Diptera: Limoniidae, Pediciidae, Tipulidae) of the Republic of Mordovia, Russia. Biodiversitas 21(1): 355-369. DOI: 10.13057/biodiv/d210143

Plavilshchikov N.N. 1964. List of insect species found in the Mordovia State Nature Reserve. Proceedings of the Mordovia State Nature Reserve 2: 105-134. [In Russian]

Rikhter V.A. 1989. 59. Family Platystomatidae. In: G.Y. BeiBienko, G.C. Steyskal (Eds.): Keys to the Insects of the European Part of the USSR. Vol. 5: Diptera and Siphonaptera, Part 2. Leiden: Brill. P. 194-196.

Roháček J., Merz B. 2013. Fauna Europaea: Clusiidae. In: T. Pape, P. Beuk (Eds.): Fauna Europaea: Diptera Brachycera. Fauna Europaea version 2017.06. Available from https://fauna-eu.org/cdm_dataportal/taxon/ c40065ea-492c-4dd2-a63f-6fa556927852

Rosenberg G.S. 2007. Cadastre of invertebrates of Samaskaya Luka. Samara: Ofort. 471 p. [In Russian]

Rozkošný R. 1987. A review of the Palaearctic Sciomyzidae (Diptera). Facultatis scientarum Naturalium Universitatis Purkynianae Brunensis, Biologia 86: 1-97.

Rozkošný R. 2013. Fauna Europaea: Sciomyzidae. In: T. Pape, P. Beuk (Eds.): Fauna Europaea: Diptera Brachycera. Fauna Europaea version 2017.06. Available from https://fauna-eu.org/cdm_dataportal/taxon/ e281d427-d787-4dfe-b998-a691c00a8e37

Ruchin A.B., Egorov L.V. 2017. Overview of insect species included in the Red Data Book of Russian Federation in the Mordovia State Nature Reserve. Nature Conservation Research 2(Suppl. 1): 2-9. DOI: 10.24189/ ncr.2017.016 [In Russian]

Ruchin A.B., Egorov L.V. 2018. Fauna of longicorn beetles (Coleoptera: Cerambycidae) of Mordovia. Russian Entomological Journal 27(2): 161-177. DOI: 10.15298/ rusentj.27.2.07

Ruchin A.B., Egorov L.V., Khapugin A.A., Vikhrev N.E., Esin M.N. 2020a. The use of simple crown traps for the insects collection. Nature Conservation Research 5(1): 87-108. DOI: $10.24189 /$ ncr.2020.008
Ruchin A.B., Carr J.F., Dvořák L., Esin M.N., Khapugin A.A. 2020b. Pseudotephritis millepunctata (Hennig, 1939) (Diptera Ulidiidae) - new species in European fauna. Redia 103: 25-27. DOI: 10.19263/REDIA-103.20.05

Shatalkin A.I. 2000. Opredelitel' palearkticheskych much semejstva Lauxaniidae (Diptera). Zoologicheskie Issledovania 5: 1-102. [In Russian]

Shtakeberg A.A. 1989a. 54. Family Megamerinidae. In: G.Y. Bei-Bienko, G.C. Steyskal (Eds.): Keys to the Insects of the European Part of the USSR. Vol. 5: Diptera and Siphonaptera, Part 2. Leiden: Brill. P. 180-182.

Shtakeberg A.A. 1989b. 71. Family Piophilidae. In: G.Y. Bei-Bienko, G.C. Steyskal (Eds.): Keys to the Insects of the European Part of the USSR. Vol. 5: Diptera and Siphonaptera, Part 2. Leiden: Brill. P. 347-350.

Shtakeberg A.A. 1989c. 78. Family Clusiidae. In: G.Y. BeiBienko, G.C. Steyskal (Eds.): Keys to the Insects of the European Part of the USSR. Vol. 5: Diptera and Siphonaptera, Part 2. Leiden: Brill. P. 505-508.

Söli G., Rindal E. 2014. The genus Sylvicola Harris, 1780 (Diptera, Anisopodidae) in Norway - with a key to the North European species. Norwegian Journal of Entomology 61: 190-200.

Soós A. 1984a. Family Platystomatidae. In: A. Soos, L. Papp (Eds.): Catalogue of Palaearctic Diptera. Vol. 9. Budapest: Akademia Kiado. P. 38-48.

Soós A. 1984b. Family Dryomyzidae. In: A. Soos, L. Papp (Eds.): Catalogue of Palaearctic Diptera. Vol. 9. Budapest: Akademia Kiado. P. 152-154.

Sorvari J. 2019. Yellow does not improve the efficiency of traps for capturing wasps of the genera Vespula and Dolichovespula (Hymenoptera: Vespidae). European Journal of Entomology 116: 240-243. DOI: 10.14411/eje.2019.027

Ševčík J. 2011. Anisopodidae and Dixidae (Diptera) of the Gemer region, with a new record for Slovakia. Casopis Slezského Zemského Muzea (Série A) 60(2): 181-184.

Uehara-Prado M., Freitas A.V.L. 2009. The effect of rainforest fragmentation on species diversity and mimicry ring composition of ithomiine butterflies. Insect Conservation and Diversity 2(1): 23-28. DOI: 10.1111/j.17524598.2008.00025.x

Vikhrev N.E., Erofeeva E.A., Ruchin A.B. 2020. Taxonomic and faunistic notes on Phaonia cincta Zetterstedt, 1846 (Diptera, Muscidae). Amurian Zoological Journal 12(1): 4-7. DOI: 10.33910/2686-9519-2020-12-1-4-7

Yaran M. 2019. A new Diptera family (Pallopteridae Loew, 1862) for the fauna of Turkey with four new records. Turkish Journal of Entomology 43(4): 451-457. DOI: 10.16970/entoted.555424

Wong J.C.H., Hanks L.M. 2016. Influence of fermenting bait and vertical position of traps on attraction of cerambycid beetles to pheromone lures. Journal of Economic Entomology 109(5): 2145-2150. DOI: $10.1093 /$ jee/tow 197 
Appendix. Characteristics of study sites in the Republic of Mordovia.

\begin{tabular}{|c|c|c|c|c|}
\hline Study site & District/Quarter & Co-ordinates & Date(s) & Habitat \\
\hline \multicolumn{5}{|c|}{ Localities outside the Mordovia State Nature Reserve } \\
\hline Svinosovkhoz & Dubenki & $54.419972^{\circ} \mathrm{N}, 46.201500^{\circ} \mathrm{E}$ & $26.07-04.08 .2019$ & mixed forest \\
\hline Kalinovka & Chamzinka & $54.401167^{\circ} \mathrm{N}, 45.903111^{\circ} \mathrm{E}$ & $26.07-04.08 .2019$ & deciduous forest \\
\hline Makarovka & Oktyabrskiy & $54.176778^{\circ} \mathrm{N}, 45.273833^{\circ} \mathrm{E}$ & $27.07-05.08 .2019$ & deciduous forest \\
\hline Saransk & Saransk & $54.176722^{\circ} \mathrm{N}, 45.265333^{\circ} \mathrm{E}$ & $05-23.08 .2019$ & deciduous forest \\
\hline \multicolumn{5}{|c|}{ Localities in Temnikov district, Mordovia State Nature Reserve (= MSNR) } \\
\hline MSNR 1 & quarter 448 & $54.708750^{\circ} \mathrm{N}, 43.196250^{\circ} \mathrm{E}$ & 01-21.08.2019 & deciduous forest \\
\hline MSNR 3 & quarter 446 & $54.718583^{\circ} \mathrm{N}, 43.220639^{\circ} \mathrm{E}$ & 02-19.08.2019 & deciduous forest \\
\hline MSNR 4 & quarter 436 & $54.727889^{\circ} \mathrm{N}, 43.149250^{\circ} \mathrm{E}$ & 02-20.08.2019 & deciduous forest \\
\hline MSNR 5 & quarter 299 & $54.798306^{\circ} \mathrm{N}, 43.146194^{\circ} \mathrm{E}$ & 01-21.08.2019 & deciduous forest \\
\hline MSNR 6 & quarter 390 & $54.769500^{\circ} \mathrm{N}, 43.303917^{\circ} \mathrm{E}$ & 05-17.08.2019 & mixed forest \\
\hline MSNR 7 & quarter 405 & $54.751972^{\circ} \mathrm{N}, 43.146583^{\circ} \mathrm{E}$ & $27.08-04.09 .2019$ & pine forest \\
\hline MSNR 8 & quarter 381 & $54.760694^{\circ} \mathrm{N}, 43.170167^{\circ} \mathrm{E}$ & $27.08-04.09 .2019$ & mixed forest \\
\hline MSNR 9 & quarter 422 & $54.730222^{\circ} \mathrm{N}, 43.129222^{\circ} \mathrm{E}$ & $28.08-04.09 .2019$ & floodplain forest \\
\hline MSNR 10 & quarter 365 & $54.770778^{\circ} \mathrm{N}, 43.304472^{\circ} \mathrm{E}$ & 05-17.08.2019 & mixed forest \\
\hline MSNR 12 & quarter 338 & $54.780278^{\circ} \mathrm{N}, 43.319833^{\circ} \mathrm{E}$ & 05-17.08.2019 & mixed forest \\
\hline MSNR 13 & quarter 421 & $54.731583^{\circ} \mathrm{N}, 43.119667^{\circ} \mathrm{E}$ & $28.08-04.09 .2019$ & floodplain forest \\
\hline MSNR 14 & quarter 414 & $54.756389^{\circ} \mathrm{N}, 43.285778^{\circ} \mathrm{E}$ & $05-17.08 .2019$ & pine forest \\
\hline MSNR 15 & quarter 442 & $54.731472^{\circ} \mathrm{N}, 43.260139^{\circ} \mathrm{E}$ & $27.08-05.09 .2019$ & mixed forest \\
\hline MSNR 16 & quarter 402 & $54.733167^{\circ} \mathrm{N}, 43.106139^{\circ} \mathrm{E}$ & $28.08-04.09 .2019$ & floodplain meadow \\
\hline MSNR 17 & quarter 402 & $54.737083^{\circ} \mathrm{N}, 43.093417^{\circ} \mathrm{E}$ & $28.08-04.09 .2019$ & floodplain forest, forest glade \\
\hline MSNR 18 & quarter 402 & $54.741944^{\circ} \mathrm{N}, 43.093667^{\circ} \mathrm{E}$ & $28.08-04.09 .2019$ & floodplain forest, lake shore \\
\hline MSNR 19 & quarter 389 & $54.768000^{\circ} \mathrm{N}, 43.301944^{\circ} \mathrm{E}$ & $05-17.08 .2019$ & pine forest \\
\hline MSNR 20 & quarter 403 & $54.744944^{\circ} \mathrm{N}, 43.118889^{\circ} \mathrm{E}$ & $27.08-04.09 .2019$ & floodplain forest \\
\hline MSNR 21 & quarter 421 & $54.731000^{\circ} \mathrm{N}, 43.115000^{\circ} \mathrm{E}$ & $28.08-04.09 .2019$ & floodplain meadow \\
\hline MSNR 22 & quarter 430 & $54.737444^{\circ} \mathrm{N}, 43.266611^{\circ} \mathrm{E}$ & $27.08-05.09 .2019$ & mixed forest \\
\hline MSNR 23 & quarter 429 & $54.735694^{\circ} \mathrm{N}, 43.264278^{\circ} \mathrm{E}$ & $27.08-05.09 .2019$ & mixed forest \\
\hline MSNR 24 & quarter 413 & $54.755083^{\circ} \mathrm{N}, 43.283167^{\circ} \mathrm{E}$ & 05-17.08.2019 & pine forest \\
\hline MSNR 25 & quarter 431 & $54.746778^{\circ} \mathrm{N}, 43.274000^{\circ} \mathrm{E}$ & $27.08-05.09 .2019$ & mixed forest \\
\hline MSNR 26 & quarter 412 & $54.750333^{\circ} \mathrm{N}, 43.273000^{\circ} \mathrm{E}$ & $27.08-05.09 .2019$ & mixed forest \\
\hline MSNR 27 & quarter 409 & $54.745528^{\circ} \mathrm{N}, 43.216278^{\circ} \mathrm{E}$ & 19.09-02.10.2019 & mixed forest \\
\hline MSNR 30 & quarter 360 & $54.771861^{\circ} \mathrm{N}, 43.226444^{\circ} \mathrm{E}$ & 19.09-02.10.2019 & mixed forest \\
\hline MSNR 31 & quarter 361 & $54.773361^{\circ} \mathrm{N}, 43.241917^{\circ} \mathrm{E}$ & 19.09-02.10.2019 & mixed forest \\
\hline MSNR 32 & quarter 406 & $54.744167^{\circ} \mathrm{N}, 43.172611^{\circ} \mathrm{E}$ & 04-16.10.2019 & pine forest \\
\hline MSNR 33 & quarter 383 & $54.754361^{\circ} \mathrm{N}, 43.203167^{\circ} \mathrm{E}$ & $19.09-02.10 .2019$ & mixed forest \\
\hline MSNR 34 & quarter 306 & $54.794194^{\circ} \mathrm{N}, 43.248889^{\circ} \mathrm{E}$ & $02-10.10 .2019$ & pine forest \\
\hline MSNR 35 & quarter 384 & $54.758056^{\circ} \mathrm{N}, 43.215194^{\circ} \mathrm{E}$ & 19.09-02.10.2019 & mixed forest \\
\hline MSNR 36 & quarter 280 & $54.795722^{\circ} \mathrm{N}, 43.247750^{\circ} \mathrm{E}$ & $02-10.10 .2019$ & pine forest \\
\hline MSNR 37 & quarter 445 & $54.719639^{\circ} \mathrm{N}, 43.217750^{\circ} \mathrm{E}$ & 04-16.10.2019 & deciduous forest \\
\hline MSNR 38 & quarter 333 & $54.783389^{\circ} \mathrm{N}, 43.250083^{\circ} \mathrm{E}$ & $02-10.10 .2019$ & pine forest \\
\hline MSNR 39 & quarter 439 & $54.723944^{\circ} \mathrm{N}, 43.209417^{\circ} \mathrm{E}$ & 04-16.10.2019 & mixed forest \\
\hline MSNR 40 & quarter 383 & $54.763389^{\circ} \mathrm{N}, 43.187889^{\circ} \mathrm{E}$ & $16-31.10 .2019$ & pine forest \\
\hline MSNR 41, PL & quarter 448 & $54.708750^{\circ} \mathrm{N}, 43.196250^{\circ} \mathrm{E}$ & 21-27.08.2019 & deciduous forest \\
\hline MSNR 41, PH & quarter 448 & $54.708750^{\circ} \mathrm{N}, 43.196250^{\circ} \mathrm{E}$ & 21-27.08.2019 & deciduous forest \\
\hline MSNR 41, QL & quarter 448 & $54.708750^{\circ} \mathrm{N}, 43.196250^{\circ} \mathrm{E}$ & 21-27.08.2019 & deciduous forest \\
\hline MSNR 41, QH & quarter 448 & $54.708750^{\circ} \mathrm{N}, 43.196250^{\circ} \mathrm{E}$ & 21-27.08.2019 & deciduous forest \\
\hline MSNR 41, AL & quarter 448 & $54.708750^{\circ} \mathrm{N}, 43.196250^{\circ} \mathrm{E}$ & 21-27.08.2019 & deciduous forest \\
\hline MSNR 41, AH & quarter 448 & $54.708750^{\circ} \mathrm{N}, 43.196250^{\circ} \mathrm{E}$ & 21-27.08.2019 & deciduous forest \\
\hline MSNR 42, TL & quarter 436 & $54.727889^{\circ} \mathrm{N}, 43.140917^{\circ} \mathrm{E}$ & 21-27.08.2019 & mixed forest \\
\hline MSNR 42, TH & quarter 436 & $54.727889^{\circ} \mathrm{N}, 43.140917^{\circ} \mathrm{E}$ & 21-27.08.2019 & mixed forest \\
\hline MSNR 42, BH & quarter 436 & $54.727889^{\circ} \mathrm{N}, 43.140917^{\circ} \mathrm{E}$ & 21-27.08.2019 & mixed forest \\
\hline MSNR 42, BL & quarter 436 & $54.727889^{\circ} \mathrm{N}, 43.140917^{\circ} \mathrm{E}$ & 21-27.08.2019 & mixed forest \\
\hline MSNR 42, AL & quarter 436 & $54.727889^{\circ} \mathrm{N}, 43.140917^{\circ} \mathrm{E}$ & 21-27.08.2019 & mixed forest \\
\hline MSNR 42, AH & quarter 436 & $54.727889^{\circ} \mathrm{N}, 43.140917^{\circ} \mathrm{E}$ & $21-27.08 .2019$ & mixed forest \\
\hline MSNR 42, QL & quarter 436 & $54.727889^{\circ} \mathrm{N}, 43.140917^{\circ} \mathrm{E}$ & $21-27.08 .2019$ & mixed forest \\
\hline MSNR 42, QH & quarter 436 & $54.727889^{\circ} \mathrm{N}, 43.140917^{\circ} \mathrm{E}$ & 21-27.08.2019 & mixed forest \\
\hline MSNR 43 & quarter 330 & $54.777333^{\circ} \mathrm{N}, 43.184194^{\circ} \mathrm{E}$ & $16-31.10 .2019$ & pine forest \\
\hline MSNR 44 & quarter 281 & $54.796417^{\circ} \mathrm{N}, 43.252194^{\circ} \mathrm{E}$ & $02-10.10 .2019$ & raised bog \\
\hline MSNR 45 & quarter 358 & $54.770861^{\circ} \mathrm{N}, 43.186556^{\circ} \mathrm{E}$ & $16-31.10 .2019$ & young post-fire forest \\
\hline MSNR 46 & quarter 283 & $54.803972^{\circ} \mathrm{N}, 43.280667^{\circ} \mathrm{E}$ & $02-10.10 .2019$ & pine forest \\
\hline MSNR 47 & quarter 445 & $54.719556^{\circ} \mathrm{N}, 43.219167^{\circ} \mathrm{E}$ & $04-16.10 .2019$ & mixed forest \\
\hline MSNR 48 & quarter 307 & $54.796222^{\circ} \mathrm{N}, 43.266028^{\circ} \mathrm{E}$ & $02-10.10 .2019$ & pine forest \\
\hline MSNR 49 & quarter 305 & $54.786722^{\circ} \mathrm{N}, 43.249111^{\circ} \mathrm{E}$ & $02-10.10 .2019$ & pine forest \\
\hline MSNR 50 & quarter 334 & $54.779194^{\circ} \mathrm{N}, 43.250917^{\circ} \mathrm{E}$ & 19.09-02.10.2019 & mixed forest \\
\hline
\end{tabular}

Note: At the localities MSNR 41 and MSNR 42, the traps were hung on different trees at two heights, named as «low» (1.5 m) and «high» (5-7 $\mathrm{m})$ on various tree species: Tilia cordata Mill., Betula pendula Roth, Alnus glutinosa (L.) Gaertn., Quercus robur L., Pinus sylvestris L. Abbreviations added to the locality name refer to tree species (T: Tilia cordata, B: Betula pendula, A: Alnus glutinosa, Q: Quercus robur, P: Pinus sylvestris) and height (H: high, L: low). 
НЕКОТОРЫЕ СЕМЕЙСТВА ДВУКРЫЛЫХ (DIPTЕRА), ПОЙМАННЫХ ПИВНЫМИ ЛОВУШКАМИ В РЕСПУБЛИКЕ МОРДОВИЯ (РОССИЯ)

\author{
Л. Дворжак ${ }^{1, *}$, К. Дворжакова ${ }^{1}$, Й. Обоня${ }^{2}$, А. Б. Ручин ${ }^{3}$ \\ ${ }^{1}$ Трши Секери, Республика Чехия \\ ${ }^{2}$ Прешовский университет, Словакия \\ ${ }^{3}$ Объединенная дирекиия Мордовского государственного природного заповедника \\ имени П.Г. Смидовича и национального парка «Смольный», Россия \\ *e-mail: lib.dvorak@seznam.cz
}

\begin{abstract}
Мы исследовали фауну некоторых семейств двукрылых (Diptera), пойманных с помощью пивных ловушек. В данной статье представлены данные о 36 видах из 12 семейств двукрылых, в т.ч. четырех видах семейства Anisopodidae, одного - Bibionidae, одного - Clusiidae, двух - Dryomyzidae, одиннадцати - Lauxaniidae, пяти - Limoniidae, одного - Megamerinidae, трех - Pallopteridae, одного - Piophilidae, одного - Platystomatidae, четырех - Sciomyzidae и двух - Ulidiidae. Из них три вида явились новыми для фауны России (Calliopum splendidum, Homoneura biumbrata, Sapromyza schnabli, все относятся к семейству Lauxaniidae), два вида - для Европейской России (Sylvicola fuscatoides (Anisopodidae), Myennis sibirica (Ulidiidae)). Впервые для Республики Мордовия и Мордовского государственного заповедника приводятся семейства Anisopodidae, Clusiidae, Megamerinidae, Pallopteridae, Piophilidae, Platystomatidae, Ulidiidae, Lauxaniidae, обнаруженные в результате настоящего исследования. Два вида семейства Limoniidae (Achyrolimonia neonebulosa и Discobola parvispinula) и три вида семейства Sciomyzidae (Euthycera chaerophylli, Tetanocera ferruginea и T. freyi) впервые отмечены для территории Мордовского заповедника. Пивные ловушки рекомендуются как один из методов для дальнейших исследований Diptera на территории исследования.
\end{abstract}

Ключевые слова: Anisopodidae, Bibionidae, Clusiidae, Dryomyzidae, Limoniidae, биоразнообразие, ловушки с приманкой, Мордовский государственный заповедник, новые находки, фаунистическое исследование 